\title{
PROPOSALS FOR TREATING FOUR SPECIES COMPLEXES IN FICUS SUBGENUS UROSTIGMA SECTION AMERICANAE (MORACEAE)
}

\author{
C.C. BERG \\ Bergen Museum, University of Bergen, Allégate 41, 5007 Bergen, Norway; \\ Nationaal Herbarium Nederland, Universiteit Leiden branch, P.O. Box 9514, 2300 RA Leiden, \\ The Netherlands; berg@nhn.leidenuniv.nl
}

\section{SUMMARY}

Four species complexes of Ficus subg. Urostigma sect. Americanae (Moraceae) are discussed. Four new combinations are made in Ficus americana Aubl.: subsp. andicola (Standl.) C.C. Berg, subsp. greiffiana (Dugand) C.C. Berg, subsp. guianensis (Desv.) C.C. Berg, and subsp. subapiculata (Miq.) C.C. Berg.

Key words: Ficus, sect. Americanae, species complexes, Neotropics.

\section{INTRODUCTION}

The American Ficus flora comprises some taxonomic complexes for which numerous names have been created and in which morphologically, phytogeographically and/or ecologically definable entities cannot be satisfactorily distinguished. These complexes have been indicated by Berg \& Simonis (1981) and Berg (1989). I have tried as long as possible to distinguish entities at the species level (see, e.g., Berg et al., 1986; Berg, 1992; Berg \& Simonis, 2000; Berg \& Villavicencio, 2004), although not very consistently as with regard to naming and defining. These attempts could not be perpetuated. With the aim to write a monograph of the neotropical sections of Ficus, numerous specimens from the whole range of distribution have been simultaneously compared to arrive at acceptable solutions for the treatment of the complexes. Moreover, the acceptance (Brummitt, 2005) of some of the proposals to conserve and reject some names within the complexes (Berg, 2003) made it possible to elaborate on solutions.

The complexes indicated were the $F$. americana, F. aurea, F. citrifolia, F. obtusifolia, F. pertusa, and F. trigonata complexes. The elements of the F. obtusifolia and F. trigonata complexes could gradually be recognised as more or less clearly definable species. The others continued to cause taxonomic problems for which solutions are proposed in the present paper.

\section{FICUS AMERICANA COMPLEX}

The names I have been applying were:

- Ficus americana (s. str.) for material in the present publication included in subsp. americana; 
- Ficus andicola for montane non-ramiflorous material from Colombia and Ecuador, in the present publication included in subsp. andicola;

- Ficus clusiifolia for ramiflorous material from eastern Brazil, in the present publication included in subsp. guianensis - 'clusiifolia-form';

- Ficus greiffiana for non-ramiflorous, mainly Amazonian material, in the present publication under subsp. greiffiana;

- Ficus guianensis for South American ramiflorous material with relatively large figs and relatively long peduncles (incorrectly so, as the type has small figs!), in the present publication referred to subsp. guianensis - 'parkeriana-form';

- Ficus maitin for montane non-ramiflorous material from northern Venezuela, in the present publication referred to subsp. andicola - 'maitin-form';

- Ficus mathewsii for South American material with small figs and short peduncles, in the present publication included in subsp. guianensis - 'mathewsii-form';

- Ficus subapiculata for mainly Amazonian ramiflorous material with figs with a sunken ostiole, in the present publication in subsp. subapiculata.

The most satisfactory solution for treating this complex is to subdivide it under the name $F$. americana Aubl. into five subspecies.

Seven collections examined cannot be included in any of the subspecies recognised.

The distribution of subspecies and informal entities is presented in Map 1,2, and 3, which are based on a (limited) set of specimens recently examined.

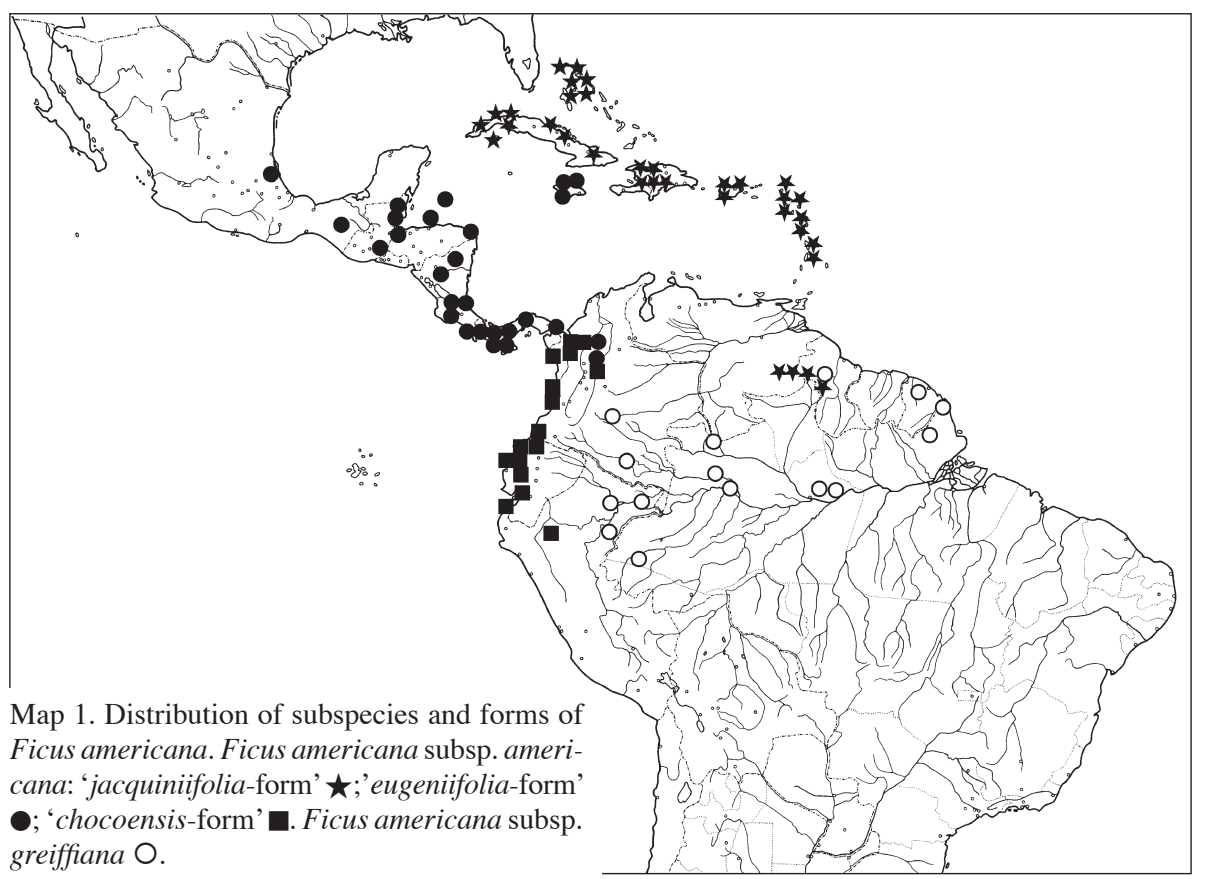



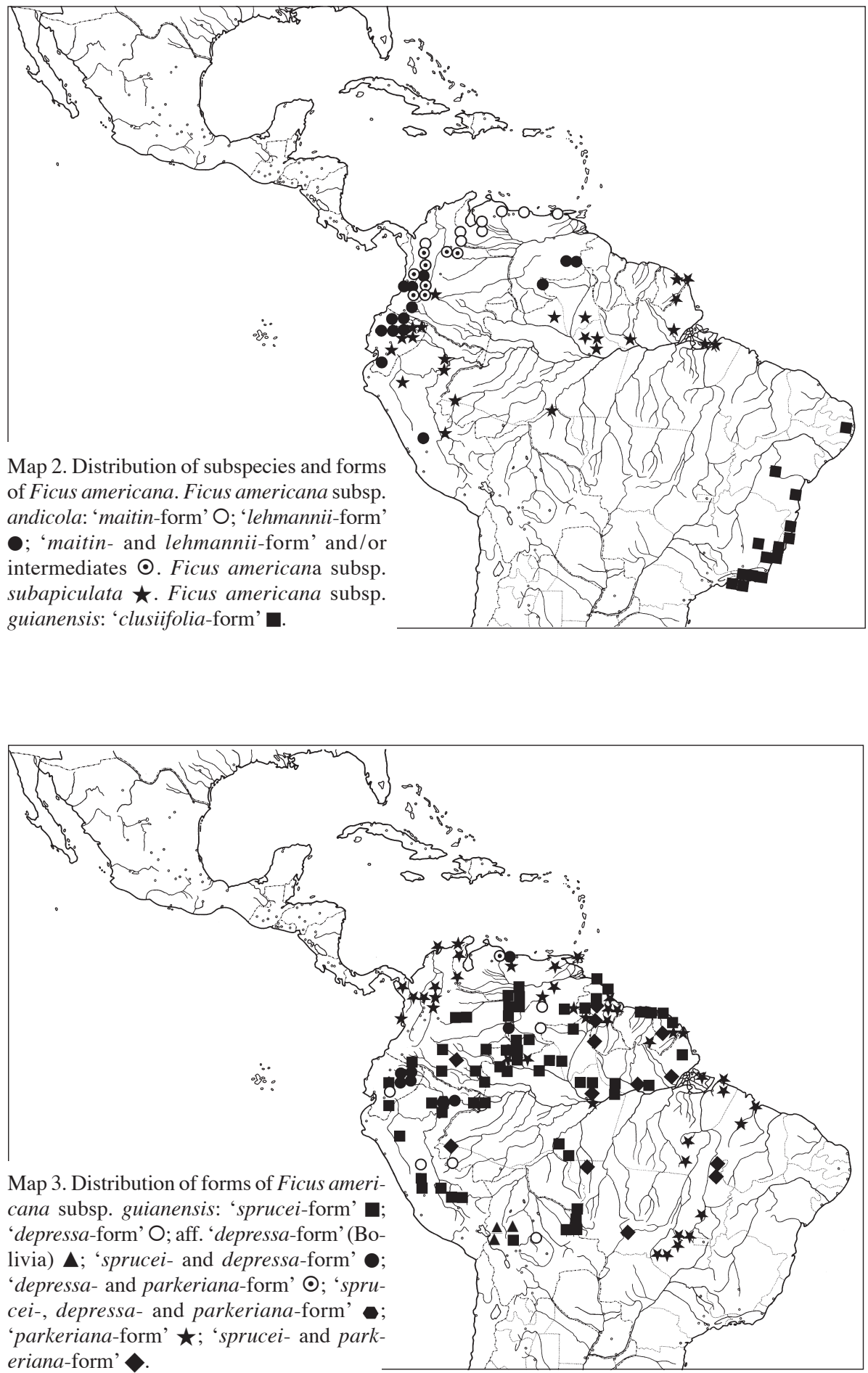


\section{Ficus americana Aubl.}

Ficus americana Aubl. (1775) 952, nom. conserv. - Ficus perforata L. (1775) 17, nom. rej. - Type: [icon] Plumier, Pl. Amer. (ed. Burman) (1757) t. 132, f. 2.

\section{KEY TO THE SUBSPECIES}

1a. Figs axillary or just below the leaves, usually in pairs $\ldots \ldots \ldots \ldots \ldots 2$

b. Figs on short-shoots below the leaves, often more than 2 together . . . . . . . 4

2a. Peduncle $0-0.6 \mathrm{~cm}$ long, basal bracts (1-)2-5(-6) $\mathrm{mm}$ long; at altitudes between (500-)1200 and $3000 \mathrm{~m}$. - South America (Andean region, in Venezuela also Coastal Mountain Range and Tepui region) ............ B. subsp. andicola

b. Peduncle $0.2-1.2 \mathrm{~cm}$ long, basal bracts $1-2(-2.5) \mathrm{mm}$ long . . . . . . . 3

3a. Apex of lamina rounded to obtuse or acuminate and base obtuse to cuneate; upper and lower surface of lamina when dry almost similar; at altitudes up to $1000 \mathrm{~m}$ or in the Tepui region 1300-2000 m. - West Indies, Mexico, Central America, Pacific coastal region of Colombia and Ecuador, Tepui region (Venezuela and Guyana) $\ldots \ldots \ldots \ldots \ldots \ldots \ldots \ldots \ldots \ldots \ldots \ldots \ldots \ldots \ldots \ldots \ldots \ldots$. subsp. americana

b. Apex of lamina subacute to acuminate and base mostly cuneate; upper and lower surface of lamina when dry usually different; at low altitudes. - Northern Amazon

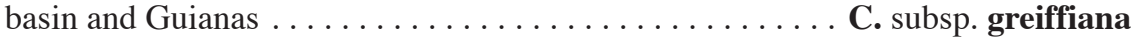

4a. Ostiole superficial; fig receptacle $0.3-0.5(-1) \mathrm{cm}$ diam.; peduncle $(0.1-) 0.2-0.3$ cm long. - South America (widespread) . . . . . . . . D. subsp. guianensis

b. Ostiole sunken in apex of fig receptacle; fig receptacle $0.4-1.3 \mathrm{~cm}$ diam.; peduncle 0.1-0.6 cm long. - Northern Amazon region and French Guiana . . . . . . . . .

E. subsp. subapiculata

\section{A. subsp. americana}

?Ficus arbutifolia Link (1822) 450. - Type: Hort. Bot. Berol. (holo B), origin unknown.

Ficus jacquiniifolia A. Rich. (1841-1851) 221, t. 72. - Type: De la Sagra s.n. (holo P; iso P), Cuba, without locality.

?Ficus periplocifolia Kunth \& C.D. Bouché (1847) 16. - Type: Hort. Bot. Berol. (holo B), origin unknown, 17 Sept. 1846.

?Ficus consanguinea Kunth \& C.D. Bouché (1847) 17. - Urostigma consanguineum (Kunth \& C.D. Bouché) Miq. (1862) 408. - Type: Hort. Bot. Berol. (holo B; iso U), origin unknown.

Urostigma eugeniaefolium Liebm. (1851) 329. - Ficus eugeniifolia (Liebm.) Hemsl. (1883) 144. - Type: Oersted 14311 (holo C; iso US), Costa Rica, Ujaras.

Urostigma chiriquianum Miq. (1862) 412. - Ficus chiriquiana (Miq.) Miq. (1867b) 298. - Type: Warszewicz s.n. (holo? B), Panama, Mountains of Chiriquí.

Urostigma liebmannianum Miq. (1854) 195. - Ficus liebmanniana (Miq.) Miq. (1867b) 298. - Type: Seemann 497 (holo BM), Panama, Chagres River.

Urostigma oerstedianum Miq. (1854) 196. - Ficus oerstediana (Miq.) Miq. (1867b) 299. - Type: Seemann 1158 (holo BM), Panama, Chiriquí, Chiriquí Volcano.

Ficus fadyenii Miq. (1867a) 219. - Type: MacFadyen s.n. (holo U; iso L), Jamaica, without locality.

Ficus sintenisii Warb. (1903) 464. - Type: Sintenis 1346 (lecto B; isolecto G, GH, LD, M, NY, P, S), Puerto Rico, Sierra de Luquillo, Jimenes.

Ficus omphalophora Warb. (1903) 466. - Type: Bertero s.n. (lecto B; isolecto M), Guadeloupe, without locality. 
Ficus wilsonii Warb. (1903) 467. - Type: Wilson 347 (lecto B), Jamaica, without locality.

Ficus chocoensis Dugand (1942a) 35. - Type: Archer 2169 (holo US), Colombia, Chocó, Río Tutunendo, E of Quibdó.

Ficus georgii Standl. \& L.O. Williams (1951) 236. - Type: León 2560 (holo US), Costa Rica, Cartago, Turrialba, Pejibaye.

The quality of the types for the names indicated with a ? (here and below) is such that their identity remains uncertain.

Distribution - West Indies to southern Mexico and through Central America to the Pacific coastal regions of Colombia, Ecuador, and northern Peru, in humid and dry forest, at altitudes up to $1000(-1500) \mathrm{m}$; also in the Tepui region of Venezuela and the adjacent part of Guyana at altitudes between 1300 and $2200 \mathrm{~m}$.

Note - Three informal entities can be distinguished on the basis of (average) differences in dimensions of lamina and fig and the prominence of the venation of the lamina above:

a. 'jacquiniifolia-form' with relatively small laminas with the venation prominent above and small figs, occurring in the West Indies (except for Jamaica) and in mountains of Guyana and eastern Venezuela;

b. 'eugeniifolia-form' with relatively small laminas with the venation plane above and with small figs, occurring in Jamaica, southern Mexico, Central America, and northern Colombia (Antioquia);

c. 'chocoensis-form' with relatively large laminas (mostly $10-20 \mathrm{~cm}$ long) and relatively large figs (usually $0.8-1.2 \mathrm{~cm}$ diam.), occurring in the Pacific coastal region of Colombia, Ecuador, and northern Peru.

B. subsp. andicola (Standl.) C.C. Berg, comb. \& stat. nov.

Ficus andicola Standl. (1937b) 167. - Type: Lehmann 5807 (holo F; iso GH, US), Colombia, Cauca, near Popayán, 1500-1600 m.

Ficus lehmannii Standl. (1929) 202. - Type: Lehmann 5607 (holo US; iso B, F, G), Colombia, Cauca, Popayán, 1500-1800 m.

Ficus archeri Standl. (1937b) 167. - Type: Archer 3369 (holo F; iso COL, US), Colombia, Cauca, near Popayán.

Ficus popayanensis Standl. (1937b) 174. - Type: Lehmann 5608 (holo F), Colombia, Cauca, Víbora, Andes of Popayán, 1300-1600 m.

Ficus maitin Pittier (1937) 73. - Type: Gehringer 450 (holo VEN; iso A, G, US), Venezuela, Mérida, near Tabay, $1800-2000 \mathrm{~m}$.

Ficus ovalifolia Pittier (1937) 73, non Ridl. (1916). - Ficus depressa Pittier (1943) 258. - Type: Pittier 13162 (holo VEN; iso G, US), Venezuela, Trujillo, near El Rosario, road Valera-Timotes, $1200 \mathrm{~m}$.

Ficus rigidifolia Pittier (1937) 79. - Type: Christ 48 (holo VEN; iso G, US), Venezuela, Trujillo, La Cuchilla.

Ficus cundinamarcensis Dugand (1942a) 36. - Type: Pérez-Arbeláez 10221 (holo COL; iso COL), Colombia, Cundinamarca, Santander, below El Salto, Río Bogotá, 1600 m.

Ficus estanislana Dugand (1942a) 43. - Type: Hno. Nicéforo \& Hno. Estanislao 3 (holo COL), Colombia, Norte de Santander, Bochalema, $1170 \mathrm{~m}$.

Ficus machetana Dugand (1942a) 55. - Type: Cuatrecasas 9671 (holo COL; iso F, US), Colombia, Cundinamarca, between Machetá and Guateque, 1800-1900 m.

Ficus soatensis Dugand (1942b) 37. - Type: Cuatrecacas \& García-Barriga 1061 (holo COL; iso F, US), Colombia, Boyacá, Soatá, 2130 m. 
Ficus chaponensis Dugand (1942b) 38. - Type: Lawrance 273 (holo US; iso A, F, G, MICH, NY), Colombia, Boyacá, region of Mt Chapón, c. 1200 m.

?Ficus fresnoensis Dugand (1943b) 272. - Type: García-Barriga 8222 (holo COL; iso NY, US), Colombia, Tolima, El Fresno, 'Cuchilla del Topacio', 1680 m.

Ficus soatensis Dugand var. bogotensis Dugand (1955) 239. - Type: Duque-Jaramillo 2940 (holo COL; iso F, US), Colombia. Cundinamarca, Bogotá, Parque de San Diego, 2620 m.

The type of F. guntheri J.H. Torres (1985) has not been examined; it might represent a hairy form of subsp. andicola.

Distribution - From the Coastal Mountain Range of Venezuela through the Andes to northern Ecuador, also in the Tepui region of Venezuela, southern Ecuador and Central Peru; in montane and submontane forest (or scrub); at altitudes between (500-) 1200-3000 m.

Notes - 1. At altitudes below $1500 \mathrm{~m}$ on the western slopes of the Andes, this subspecies cannot always be distinguished from the 'chocoensis-form' of subsp. americana.

2. Two informal entities can be recognised. However, in the region where they cooccur, intermediates are numerous:

a. 'lehmannii-form' with lamina often longer than $10 \mathrm{~cm}$, fig receptacles $0.8-1.3 \mathrm{~cm}$ diam., and basal bracts 2-5 mm long, occurring in the Andean region of Colombia and northern Ecuador, and northern and central Peru, and in the Tepui region of Venezuela;

b. 'maitin-form' with lamina often less than $10 \mathrm{~cm}$ long, fig receptacles $0.5-0.7 \mathrm{~cm}$ diam., and basal bracts 1-3 mm long, occurring in the Coastal Mountain Range of Venezuela to southern Andean Colombia (Cauca).

C. subsp. greiffiana (Dugand) C.C. Berg, comb. \& stat. nov.

Ficus greiffiana Dugand (1942a) 49. - Type: Cuatrecasas 8884 (holo COL; iso F, US), Colombia, Caquetá, Florencia, Buenavista.

Distribution - Guyana and French Guiana and northern Amazon Basin to Colombia and Peru, in humid forest at low altitudes.

D. subsp. guianensis (Desv.) C.C. Berg, stat. \& comb. nov.

Ficus guianensis Desv. (1825) 62. - Type: Martin s.n.? (holo P), French Guiana, without locality. Ficus clusiifolia Schott (1827) 409. - Urostigma clusiifolium (Schott) Miq. (1847) 543. - Type: Schott s.n. (holo B), Brazil, without locality.

?Ficus splendens Kunth \& C.D. Bouché (1847) 14. - Type: Hort. Bot. Berol., origin unknown (holo B, not found, probably represented by material in U, ex Hort. Bot. Berol. 1848 and ex Hort. Berol. 1851).

?Ficus anacardiifolia Kunth \& C.D. Bouché (1847) 15. - Type: Hort. Bot. Berol., origin unknown (holo B; iso U).

Urostigma mathewsii Miq. (1847) 549. - Ficus mathewsii (Miq.) Miq. (1867) 298. - Type: Mathews 2059 (holo K, not found in 2001, but see DeWolf (1975) 251), Peru, without locality.

Pharmacosycea parkeriana Miq. (1848) 71. - Ficus parkeriana (Miq.) Sandwith (1932) 227. - Type: Parker s.n. (holo K; iso E, G), Guyana, Demerara.

Ficus martinii Miq. (1867a) 219. - Type: Martin s.n. (holo U; iso B, G, K, L, NY, P, R; the same collection as that of the type of $F$. guianensis?), French Guiana, without locality. 
Ficus umbonigera Warb. (1903) 480. - Type: Hart 1808 (holo not found in B; iso TRIN, US), Trinidad, between Latrea and Irais.

Ficus grenadensis Warb. (1903) 481. - Type: Eggers 6138 (holo B; iso GH, US), Grenada, near Plaisance.

Ficus oblanceolata Rusby (1907) 446. - Type: Bang 2369 (holo NY; iso B, C, F, G, LD, LE, M, MICH, MIN, O, US), Bolivia, Sud Yungas, Coroico.

Ficus gleasonii Standl. (1937b) 170. - Type: De la Cruz, 2396 (holo F; iso GH, K, NY, US), Guyana, Upper Mazaruni River.

Ficus sprucei Standl. (1937b) 176. - Type: Spruce 2804 (holo F; iso C, COL, E, GH, LE, NY, P), Brazil, Amazonas, Rio Uaupés, near Panuré.

Ficus myriasycea Pittier (1937) 75. - Type: Pittier 11924 (holo VEN; iso A, US), Venezuela, Distrito Federal, Caruao.

Ficus niceforoi Dugand (1942a) 59. - Type: Hno. Nicéforo s.n. (holo COL), Colombia, Meta, Villavicencio.

Ficus vaupesana Dugand (1942a) 72. - Type: Cuatrecacas 7308 (holo COL; iso F, US), Colombia, Vaupés, Río Vaupés, Yuruparí.

Ficus metensis Dugand (1943a) 77. - Type: Cuatrecasas \& García-Barriga 4332 (holo US; iso COL, F), Colombia, Meta, Río Orocué.

Ficus corpulenta Pittier (1943) 257. - Type: Ll. Williams 15237 (holo VEN; iso US), Venezuela, Amazonas, between Tamatama and Esmeralda, Isla Solitaria.

Ficus maroana Pittier (1944) 120. - Type: Ll. Williams 14427 (holo VEN; iso G, RB, US), Venezuela, Amazonas, Río Guainía, Maroa.

Ficus chiribiquetensis Dugand (1944) 375. - Type: Schultes 5445 (holo COL; iso COL, US), Colombia, Vaupés, Río Macaya, Cerro Chiribiquete.

Ficus erratica Standl. (1948) 295. - Type: Fanshawe 2436 = FD 5172 (holo F; iso A, K, NY, U, US), Guyana, Aruka River, Mabaruma.

Ficus mensalis Standl. (1948) 297. - Type: Maguire 24584 (holo F; iso A, K, MO, NY, U, US), Surinam, Tafelberg, $2 \mathrm{~km} \mathrm{~S}$ of East Ridge.

Distribution - From the Lesser Antilles (Grenada and St. Vincent), Tobago, and Trinidad, to northern South America, westwards to parts of Antioquia and Chocó (Colombia), to the Guianas, the Amazon Basin, and eastern and central Brazil; in humid forest and savannah forest; at low altitudes, or on the eastern slopes of the Andes in submontane forest at altitudes up to $2100 \mathrm{~m}$.

Notes -1 . This subspecies is very variable in size and shape of the lamina, and in the dimensions and shape of the fig receptacle, the length of the peduncle and basal bracts, a variation that allows recognition of three main informal entities:

a. 'mathewsii-form' with small figs, mostly $0.3-0.4 \mathrm{~cm}$ diam., peduncle $0.1-0.4$ $\mathrm{cm}$ long, and basal bracts varying from $0.5-4 \mathrm{~mm}$ long; the lamina varies from small to large. It is widespread and common in the Amazon Basin, the Guianas, and the lowlands of north-western South America, in humid forest and savannah, at altitudes up to $1000 \mathrm{~m}$, and on the eastern slopes of the Andes, in submontane forest, at altitudes up to $2100 \mathrm{~m}$. This form is quite variable and two subforms can be recognised;

a'. 'spruce $i$-subform' with laminas usually small, up to $10 \mathrm{~cm}$ long, the fig receptacle subglobose and small, 0.3-0.4(-0.5) cm diam., and the basal bracts small, 0.5-1 $\mathrm{mm}$ long. It is found in the greater part of the range of the form, occurring at altitudes up to $2100 \mathrm{~m}$;

a". 'depressa-subform' with laminas small to medium-sized, the fig receptacle depressed-globose, and the basal bracts relatively large, 2-3(-4) $\mathrm{mm}$ long. It 
is mainly found in the upper Amazon Basin and the foothills of the Andes in Venezuela and from Ecuador (Napo) to Bolivia (Santa Cruz), in Venezuela also in the Amazonas and Bolívar, at altitudes up to $1000 \mathrm{~m}$. Some collections from Bolivia have relatively large basal bracts, but the fig receptacles are not clearly depressed-globose;

b. 'clusiifolia-form' with small to medium-sized laminas mostly with rounded to obtuse apices, fig receptacle subglobose, 0.4-0.7 mm long, and basal bracts large, 2-3(-4) $\mathrm{mm}$ long. It is found in eastern Brazil (from Pernambuco to Rio de Janeiro);

c. 'parkeriana-form' with small to medium-sized laminas, fig receptacle globose, mostly $0.5-1 \mathrm{~cm}$ diam., peduncle often longer than $0.4 \mathrm{~cm}$, and basal bracts small, 1-2.5 mm long. It extends from the Lesser Antilles (Grenada and St. Vincent), Tobago, and Trinidad to northern South America, from the Guianas to Colombia (Guajira, Magdalena, Antioquia, and Chocó), the Amazon Basin (mainly the lower and middle part), and Central Brazil, in humid forest, savannah forest, gallery forest, or montane forest (in Bolivia), at altitudes up to 1300 (or 2000) $\mathrm{m}$.

2. Ficus schippii Standl., ranging from Belize to Peru (and the adjacent part of Brazil) is also ramiflorous and can usually be distinguished from $F$. americana subsp. guianensis 'sprucei-subform' by the presence of patent yellowish hairs on the midrib of the lamina beneath and/or exfoliating epidermis of the petiole. However, hairs on the midrib may be absent and only the other differentiation character present, and if the latter is weakly developed it is (almost) impossible to distinguish the taxa.

E. subsp. subapiculata (Miq.) C.C. Berg, comb. \& stat. nov.

Urostigma subapiculatum Miq. (1853) 101. - Ficus subapiculata (Miq.) Miq. (1867) 298. - Type: R. Spruce 949 (holo U; iso G, LE, M), Brazil, Amazonas, Manaus.

Distribution - French Guiana and the northern part of the Amazon Basin westwards to Colombia and Ecuador; in humid forest; at altitudes up to $1200 \mathrm{~m}$.

\section{FICUS AUREA COMPLEX}

The naming of Central American and Mexican herbarium material was linked to the preparation of a treatment of $F$. aurea for Flora Mesoamericana and because of the variation, informal entities were distinguished, but for the Caribbean material it was not necessary because of the uniformity of the material.

\section{Ficus aurea Nutt.}

Ficus aurea Nutt. (1846) 4, t. 43, nom. cons. - Type: Blodgett s.n. (holo BM; iso NY), USA, Florida, Key West.

Ficus ciliolosa Link (1822) 450, nom. rej. prop. - Type: Hort. Bot. Berol. (holo B; iso NY), origin unknown.

Ficus aurea Nutt. var. latifolia Nutt. (1846) 4. - Type: Blodgett s.n. (holo BM), USA, Florida, Key West.

Ficus venusta Kunth \& C.D. Bouché (1847) 16. - Urostigma venustum (Kunth \& C.D. Bouché) Miq. (1847) 538. - Type: Hort. Bot. Berol., origin unknown (holo B; iso U).

Urostigma tecolutense Liebm. (1851) 324. - Ficus tecolutensis (Liebm.) Miq. (1867) 299. - Type: Liebmann 14335 (holo C; iso B; iso fragments F, GH, K), Mexico, Veracruz, Río Tecoluta, Sepillo. 
Ficus dimidiata Griseb. (1859) 151. - Type: Wullschlaegel 1368 (holo GOET), Jamaica, Manchester.

Urostigma warczewiczii Miq. (1862) 410. - Ficus warczewiczii (Miq.) Miq. (1867) 298. - Type: Warzewicz s.n. (holo U), Guatemala, without locality.

Ficus tuerckheimii Standl. (1917) 13. - Type: Pittier 16149 (holo US; iso B, NY), Costa Rica, La Fortuna, Volcan de Irazú, $1575 \mathrm{~m}$.

Ficus isophlebia Standl. (1917) 14. - Type: Pittier 2821 (holo US), Panama, Chiriqui, near David. Ficus jimenezii Standl. (1917) 14. - Type: Tonduz \& O. Jiménez 17536 (holo US; iso GH), Costa Rica, near San José.

Ficus cookii Standl. (1917) 15. - Type: Cook 73 (holo US), Mexico, Chiapas, San Vincente.

Ficus lundellii Standl. (1935) 54. - Type: Lundell 3406 (holo F; iso MICH, S, US), Guatemala, Peten, La Libertad.

Ficus cabusana Standl. \& Steyerm. (1940) 226. - Type: Steyermark 37583 (holo F), Guatemala, San Marcos, Río Cabús, Potrero Matasán, Finca 'El Porvenir', 1000-1300 m.

Ficus laterisyce W.C. Burger (1973) 426. - Type: Lent 2972 (holo F; iso U, US), Costa Rica, Cartago, Río Pejibaye, $2 \mathrm{~km}$ SW of Taus.

Ficus mayana Lundell (1975) 157. - Type: Lundell \& Contreras 19266 (holo LL; iso BM, K, F, S), Guatemala, Petén, La Cumbre.

Ficus rigidula Lundell (1975) 159. - Type: Breedlove 9568 (holo LL), Mexico, Chiapas, near Tuxtla Gutierrez, $600 \mathrm{~m}$.

Ficus rzedowskiana Carvajal \& Cuevas-Figueroa (2003), of which type material has not been examined, might be included in synonymy.

Ficus sapotifolia Kunth \& C.D. Bouché (1847) 17. - Type: Hort. Berol., origin unknown (holo B), has been included in the synonymy of F. aurea, as by Fawcett \& Rendle (1914). The type proved to belong to F. obliqua G. Forst. (Berg \& Villavicencio, 2004; Berg \& Corner, 2005).

Distribution - USA (Florida), Bahama Archipelago, Caicos Islands, Greater Antilles (Hispaniola, Cuba, Jamaica), Little and Grand Cayman, San Andrés, southern Mexico, and Central America (to Panama); in various types of vegetation; at altitudes up to $1800 \mathrm{~m}$.

Note - This species is extremely variable in shape and dimensions of the leaves. It is variable in the size of the receptacles and basal bracts. The following \pm contrasting morphological features can be indicated: lamina oblong to elliptic with cuneate to rounded base vs cordiform to elliptic with cordate to rounded base; lamina small (up to c. $10 \mathrm{~cm}$ ) vs large (longer than $10 \mathrm{~cm}$ ); figs $0.6-0.8 \mathrm{~cm}$ vs $1-1.2 \mathrm{~mm}$; figs sessile vs pedunculate (only found in the northern part of Mesoamerica). Large figs usually have large basal bracts, small figs have relatively small to large basal bracts. None of the morphs can be related to certain habitats or altitudes. Taking into account the extremes in the variation, one can recognise four informal entities:

a. 'aurea-form' with the lamina oblong to elliptic, up to $10 \mathrm{~cm}$ long, base cuneate to rounded; figs $0.6-0.8 \mathrm{~cm}$ diam., sessile or pedunculate;

b. 'tuerckheimii-form' with the lamina oblong to elliptic, longer than $10 \mathrm{~cm}$, base cuneate to rounded; figs $1-1.2 \mathrm{~cm}$ diam., sessile;

c. 'isophlebia-form' with the lamina cordiform to ovate, base cordate to rounded; figs c. $1 \mathrm{~cm}$ diam., sessile;

d. 'cookii-form' with the lamina cordiform to ovate, base cordate to rounded; figs c. $1 \mathrm{~cm}$ diam., pedunculate. 


\section{FICUS CITRIFOLIA COMPLEX}

In attempts to distinguish as long as possible morphological entities to the best of my capability I have applied in the past the following names:

- Ficus amazonica for material with small leaves and figs, mainly in the Guianas and adjacent parts of the continent and Trinidad;

- Ficus brittonii for material with small leaves and figs in Curaçao, and dry parts of north-eastern Colombia and north-western Venezuela;

- Ficus citrifolia for most of the material from the West Indies, Central America and the Pacific coastal region of South America;

- Ficus dugandii for specimens with a \pm clearly cuneate base of the lamina and obovoid figs in north-western South America, Panama, and Costa Rica;

- Ficus eximia for material with large leaves and figs in the lowlands of South America, eastwards to Guyana and southwards to Argentina, and, moreover, in Panama;

- Ficus subandina for montane Andean material with large, often shortly pedunculate figs from Colombia to Bolivia.

A recent study of the type of F. eximia Schott (1827), however, made it clear that the name has to be applied for the species until recently named F. glabra Vell. (1831).

Some closely related species: Ficus krukovii Standl. can be reasonably well distinguished. The lack of sufficient collections makes the status of F. cremersii C.C. Berg slightly doubtful. Ficus aripuanensis C.C. Berg \& Kooy had to be reduced to a synonym of F. donnell-smithii Standl.

\section{Ficus citrifolia Mill.}

Ficus citrifolia Mill. (1768), nom. conserv. - Ficus catesbaei Steud. (1840) 635., nom illeg. - Type: Anonymus in herb. Miller (holo BM), West Indies (?).

Ficus caribea Jacq. (1767) 30, nom. rej. - Type: Heller 6330 (neo L), Puerto Rico, Adjuntas, 5 miles from Ponce.

Ficus pedunculata Aiton (1789) 450. - Urostigma pedunculatum (Aiton) Miq. (1847) 540. - Ficus populnea var. laevigata (Vahl) Warb. subvar. pedunculata (Aiton) Warb. (1903) 475. - Type: [icon] Plukenet, Phytographia (1692) t. 178, f. 4.

Ficus laevigata Vahl (1805) 183. - Urostigma laevigatum (Vahl) Miq. (1847) 539. - Ficus populnea Willd. var. laevigata (Vahl) Warb. (1903) 474. - Type: West s.n. (holo C), St. Croix, without locality.

Ficus lentiginosa Vahl (1805) 183. - Urostigma lentiginosum (Vahl) Liebm. (1851) 323. - Ficus populnea Willd. var. lentiginosa (Vahl) Warb. (1903) 476. - Ficus laevigata Vahl var. lentiginosa (Vahl) Urb. (1905) 198. - Type: Ryan s.n. (holo C), Montserrat, without locality.

Ficus populnea Willd. (1806) 1141. - Urostigma populneum (Willd.) Miq. (1847) 537. - Type: ex. Hort. Paris (holo B-W), origin unknown.

Ficus gigantea Kunth (1817) 49. - Urostigma giganteum (Kunth) Miq. (1847) 530. - Type: Von Humboldt \& Bonpland s.n. (or 722) (holo P; iso B), Venezuela, near Caracas.

Ficus rubrinervis Link (1822) 448. - Type: Hort. Bot. Berol. (holo B), Brazil.

?Ficus oblongata Link (1822) 449. - Type: Anonymus s.n. (holo B), Brazil?, without locality.

Ficus pedunculata Aiton. var. acuta Nutt. (1846) 2. - Type: Anonymus in herb. Nuttall (holo BM), USA, Florida, Key West.

Ficus brevifolia Nutt. (1846) 3. - Ficus populnea Willd. var. brevifolia (Nutt.) Warb. (1903) 473. - Ficus laevigata Vahl var. brevifolia (Nutt.) Rossberg (1935) 583. - Ficus citrifolia Mill. var. brevifolia (Nutt.) D’Arcy (1973) 116. - Ficus citrifolia Mill. subsp. brevifolia (Nutt.) E. Murray (1983) 6. - Type: Anonymus in herb. Nuttall (holo BM), USA, Florida, Key West. 
Ficus botryapioides Kunth \& C.D. Bouché (1847) 15. - Type: Hort. Bot. Berol. (holo B), Mexico. Ficus umbrifera Kunth \& C.D. Bouché (1847) 18. - Ficus populoides Warb. forma umbrifera (Kunth \& C.D. Bouché) Warb. (1903) 480. - Type: Hort. Bot. Berol. (holo B), origin unknown.

Ficus syringifolia Kunth \& C.D. Bouché (1847) 35. - Urostigma syringifolium (Kunth \& C.D. Bouché) Miq. (1847) 535. - Ficus populoides Warb. forma syringifolia (Kunth \& C.D. Bouché) Warb. (1903) 480. - Type: Hort. Bot. Berol. (holo B), Venezuela, Caracas, Feb 1846.

Urostigma leucostictum Miq. (1847) 535. - Ficus leucosticta (Miq.) Miq. (1867b) 297, non Spreng. (1826). - Type: Parker s.n. (holo K), Guyana, Demarara.

Urostigma amazonicum Miq. (1847) 541. - Ficus amazonica (Miq.) Miq. (1867b) 298. - Type: Von Martius s.n. (holo M; iso U), Brazil. 'Prov. Rio Negro', Amazon River.

Urostigma angustifolium Miq. (1847) 541. - Ficus angustifolia (Miq.) Miq. (1867b) 298. - Type: Parker s.n. (holo K), Guyana, Demerara.

Urostigma sancti-crucis Liebm. (1851) 328. - Ficus sancti-crucis (Liebm.) Miq. (1867b) 299. Ficus populnea Willd. var. laevigata (Vahl) Warb. subvar. sancti-crucis (Liebm.) Warb. (1903) 475. - Type: Oersted s.n. (holo C), St. Croix, without locality.

Ficus eximia Schott var. cubensis Miq. (1867b) 297. - Type: Anonymus in herb. Lips 48 (holo U), Cuba, without locality.

Ficus thomaea Miq. (1867b) 299. - Ficus populnea Willd. var. laevigata (Vahl) Warb. subvar. thomaea (Miq.) Warb. (1903) 474. - Type: Ehrenberg 236 (holo?, B), St. Thomas, without locality.

Ficus surinamensis Miq. (1867a) 219. - Type: Kegel 186 (lecto U; isolecto C?, P), Surinam, near plantation Quarta.

Ficus portoricensis Urb. (1900) 472. - Ficus populnea Willd. var. laevigata (Vahl) Warb. subvar. portoricensis (Urb.) Warb. (1903) 474. - Ficus laevigata Vahl subvar. portoricensis (Urb.) Urb. (1905) 198. - Type: Sintenis 5037 (holo not found in B; iso G, GH, LD, M, NY, S, US), Puerto Rico, near Jabucoa.

Ficus populnea Willd. var. bahamensis Warb. (1903) 473. - Type: Eggers 3800 (lecto G; isolecto M, P), Bahamas, Hog Island.

Ficus populnea Willd. var. brevifolia (Nutt.) Warb. subvar. cubana Warb. (1903) 473. - Type: Wright 544 (lecto G; isolecto NY), Cuba, without locality.

Ficus populnea Willd. var. brevifolia (Nutt.) Warb. subvar. floridana Warb. (1903) 473. - Type: Curtiss 2548 (holo B; iso LE ), USA, Florida, Meig's Key.

Ficus populnea Willd. var. laevigata (Vahl) Warb. subvar. sancti-eustachii Warb. (1903) 475. - Syntypes: Suringar s.n. (not found in B), St. Eustatius, Klif, Fairplay; Suringar s.n. (not found in B), St. Martin, without locality.

Ficus populnea Willd. var. laevigata (Vahl) Warb. subvar. sancti-joannis Warb. (1903) 475. - Syntypes: Eggers 3094 (not found in B), St. John, Klein Carmel Bay; Eggers 3260 (not found in B), St. John, Küstenberg.

Ficus populnea Willd. var. laevigata (Vahl) Warb. subvar. hispaniolae Warb. (1903) 476. - Ficus populnea Willd. var. hispaniolae (Warb.) Urb. (1920) 168. - Ficus laevigata Vahl var. hispaniolae (Warb.) Rossberg (1935) 583. - Type: Bertero s.n. (lecto G), Dominican Republic, without locality.

Ficus populnea Willd. var. lentiginosa (Vahl) Warb. subvar. subcordata Warb. (1903) 476. - Ficus laevigata Vahl var. lentiginosa (Vahl) Urb. subvar. subcordata (Warb.) Urb. (1905) 198. - Type: Sintenis 4411 (lecto L; isolecto G, GH, LD, LE, P), Puerto Rico, Adjuntas.

Ficus populnea Willd. var. lentiginosa (Vahl) Warb. subvar. cerasicarpa Warb. (1903) 477. - Ficus laevigata Vahl var. lentiginosa (Vahl) Urb. subvar. cerasicarpa (Warb.) Stehlé, M. Stehlé \& L. Quentin (1938) 180. - Type: Duss 2197 (not found in B), Guadeloupe, without locality.

Ficus populnea Willd. var. lentiginosa (Vahl) Warb. subvar. obliquicuspis Warb. (1903) 477. - Ficus laevigata Vahl var. lentiginosa (Vahl) Urb. subvar. obliquicuspis (Warb.) Urb. (1905) 198. - Type: Bertero s.n. (lecto G), Puerto Rico, without locality.

Ficus populnea Willd. var. lentiginosa (Vahl) Warb. subvar. reticulosa Warb. (1903) 477. - Ficus laevigata Vahl var. lentiginosa (Vahl) Urb. subvar. reticulosa (Warb.) Stehlé, M. Stehlé \& L. Quentin (1938) 181. - Type: Plée s.n. (holo not found in B), Martinique, without locality. 
Ficus populnea Willd. var. lentiginosa (Vahl) Warb. subvar. subdepressa Warb. (1903) 477. - Ficus laevigata Vahl var. lentiginosa (Vahl) Urb. subvar. subdepressa (Warb.) Stehlé, M. Stehlé \& L. Quentin (1938) 180. - Type: Bertero s.n. (not found in B), Guadeloupe, without locality.

Ficus populnea Willd. var. lentiginosa (Vahl) Warb. subvar. subpyriformis Warb. (1903) 477. - Ficus laevigata Vahl var. lentiginosa (Vahl) Urb. subvar. subpyriformis (Warb.) Stehlé, M. Stehlé \& L. Quentin (1938) 180. - Type: Bertero s.n. (not found in B), Guadeloupe, without locality.

Ficus populnea Willd. var. lentiginosa (Vahl) Warb. subvar. crassipetiolata Warb. (1903) 478. - Ficus laevigata Vahl var. lentiginosa (Vahl) Urb. subvar. crassipetiolata (Warb.) Stehlé, M. Stehlé \& L. Quentin (1938) 181. - Type: Hahn 1466 (lecto B; isolecto G, P), Martinique, Fort Boulet.

Ficus populnea Willd. var. lentiginosa (Vahl) Warb. subvar. diversifolia Warb. (1903) 478. - Type: Broadway 1413 (holo not found in B), Grenada, without locality.

Ficus populnea Willd. var. lentiginosa (Vahl) Warb. subvar. flavicosta Warb. (1903) 478. - Type: Eggers 6697 (lecto US; isolecto P), St. Vincent, St. Andrews.

Ficus populnea Willd. var. lentiginosa (Vahl) Warb. subvar. longipetiolata Warb. (1903) 478. - Type: Rob. Schomburgk 19 (holo not found in B), Barbados, without locality.

Ficus populnea Willd. var. lentiginosa (Vahl) Warb. subvar. subcuspidata Warb. (1903) 478. - Ficus lentiginosa Vahl var. subcuspidata (Warb.) Domin (1930) 47. - Ficus laevigata Vahl var. lentiginosa (Vahl) Urb. subvar. subcuspidata (Warb.) Stehlé, M. Stehlé \& L. Quentin (1938) 181. - Syntypes: Duss s.n. (not found in B), Dominica, without locality; Duss s.n. (not found in B), Martinique, without locality; Ramage s.n. (not found in B), Dominica, without locality.

Ficus populoides Warb. (1903) 479. - Type: Combs 366 (lecto P), Cuba, Cienfuegos, near Cieneguita.

Ficus populoides Warb. var. dilatata Warb. (1903) 480. - Type: Jaeger 189 (lecto B; isolecto E, H, LE, M), Haiti, Port-au-Prince.

Ficus populoides Warb. var. elongata Warb. (1903) 480. - Type: Eggers 5435 (holo B; iso M, P, US), Cuba, Río Purial.

Ficus populoides Warb. var. maculosa Warb. (1903) 480. - Type: Wright 1686 (lecto B; isolecto G, GH, P, US), Cuba, without locality.

Ficus brittonii Bold. (1914) 20. - Type: Boldingh 5342 (lecto U; isolecto NY), Curaçao, Hofje Hato.

Ficus eximia Schott forma paraguariensis Hassl. (1919) 125. - Type: Hassler 12102 (lecto G; isolecto BAF n.v., NY), Paraguay, Lake Yparacay.

Ficus guaranitica Chodat (1920) 254. - Type: Balansa 1986 (lecto G; isolecto P), Paraguay, near Ascuncion.

Ficus lentiginosa Vahl var. imrayana Domin (1930) 48. - Type: Imray 290 (not traced), Dominica, without locality.

Ficus dugandii Standl. (1932) 20. - Type: Dugand 27 (holo F; iso COL, G, US), Colombia, Atlántico, near Galapa.

Ficus turbinata Pittier (1937) 61, non Willd. (1806), nec (Liebm.) Miq. (1867). - Type: Pittier 12277 (holo VEN; iso B, F, G, M, MO, US), Venezuela, Distrito Federal, above Antimano, trail to Aguas Negras, $1200 \mathrm{~m}$.

Ficus expansa Pittier (1937) 63. - Type: Pittier 12421 (holo VEN; iso G, M, US), Venezuela, Distrito Federal, road Caracas-La Guiara, Quebrada de El Paují.

Ficus glandulosa Pittier (1937) 70. - Type: Pittier 12186 (holo VEN; iso A, G, US), Venezuela, Aragua, Chuao.

Ficus guanarensis Pittier (1937) 71. - Type: Pittier 12077 (holo VEN; iso A, G, LE, US), Venezuela, Portuguesa, near Guanare.

Ficus ruiziana Standl. (1937a) 307. - Type: Macbride 5795 (holo F; iso US), Peru, Junín, La Merced, $1200 \mathrm{~m}$.

Ficus foveolata Pittier (1941) 133, non (Miq.) Miq. (1867). — Ficus foveata Pittier (1943) 258. - Type: Tamayo 968 (holo VEN; iso US), Venezuela, Falcón, Pueblo Nuevo, Paraguaná.

Ficus caucana Dugand (1942a) 34. - Type: Pérez-Arbelaéz \& Cuatrecasas 6009 (holo COL; iso F, US), Colombia, Cauca, Popayán, near Venta de Cajibió, $1760 \mathrm{~m}$.

Ficus subandina Dugand (1942a) 66. - Type: Dugand \& Jaramillo M 2954 (holo COL; iso F, US), Colombia, Cundinamarca, between El Salto and El Colegia, 'Santibar' 1650-1700 m. 
Ficus manicariarum Standl. (1948) 297. - Type: Fanshawe 2434 = FD 5170 (holo F; iso K, NY, US), Guyana, Aruka River, Mabaruma.

Ficus gentlei Lundell (1961) 116. - Type: Gentle 4739 (holo LL; iso LL, S), Belize, Toledo, Río Grande.

Distribution - USA (Florida), West Indies, Mexico, and through Central America to northern Argentina; in humid to dry types of forest (or on coral rocks); at altitudes up to $2100 \mathrm{~m}$.

Notes -1 . The species is highly variable. In order to indicate the extremes and the distribution of the variation, informal entities can be applied in accordance with the species names listed above: 'amazonica-form', 'brittonii-form', etc. The misapplied epithet eximia is to be replaced by guaranitica: 'guaranitica-form'.

2. Ficus leucosticta (Miq.) Miq., F. manicariarum Standl., Urostigma leucostictum Miq., in some publications (Berg, 1992; Berg \& Simonis, 2000) treated as synonyms of F. paludica Standl. (1948), have been transferred to F. citrifolia (Berg \& Villavicencio, 2004).

\section{FICUS PERTUSA COMPLEX}

Because of the numerous intermediates between the various forms most of the material has been identified just as $F$. pertusa, but in the past other names have also been applied:

- Ficus padifolia for material with large figs;

- Ficus broadwayi for material with relatively large leaves and firmly coriaceous leaves from north-eastern South America and Trinidad has been identified, but occurrence of rather similar material, e.g., in Amazonian Peru, made distinction as species not maintainable.

Within the broad $F$. pertusa several informal entities can be distinguished (see below).

Other species which have been linked to this complex as F. lauretana Vázq. Avila, F. pallida Vahl, and F. schumacheri (Liebm.) Griseb. (see Berg et al., 1986) can be readily distinguished.

\section{Ficus pertusa L.f.}

Ficus pertusa L.f. (1782) 442. - Urostigma pertusum (L.f.) Miq. (1847) 548. - Type: Dahlberg s.n. (holo LINN.1240.9), Surinam.

Ficus padifolia Kunth (1817) 47. - Urostigma padifolium (Kunth) Liebm. (1851) 324. - Type: Von Humboldt \& Bonpland s.n. (or 3885) (holo P; iso B), Mexico, Guerrero, near Acapulco.

Ficus complicata Kunth (1817) 48. - Urostigma complicatum (Kunth) Liebm. (1851) 325. - Type: Von Humboldt \& Bonpland s.n. (or 3975) (holo P; iso B), Mexico, near Guasintla and Puente de Istla (or Isla?), c. $1000 \mathrm{~m}$.

Ficus myrtifolia Link (1822) 450. - Type: Hort. Bot. Berol. s.n. (holo B; iso? U), origin unknown. Ficus lancifolia Hook. \& Arn. (1838) 310. - Urostigma lancifolium (Hook. \& Arn.) Miq. (1847) 538. - Type: Beechey s.n. (holo K), Mexico, Nayarit, near Tepic.

Ficus subtriplinervia Mart. (1841) 67. - Urostigma subtriplinervium (Mart.) Miq. (1847) 542. - Ficus prinoides Willd. var. subtriplinervia (Mart.) Kuntze (1898) 294. - Type: Von Martius 584 (holo M; iso B, F, G, K, L, LE, NY, P, U?), Brazil, Mato Grosso, Cuiabá.

Ficus arpazusa Casar. (1842) 10. - Type: Casaretto s.n. (holo TO n.v.), Brazil, near Rio de Janeiro. 
?Ficus cerasifolia Kunth \& C.D. Bouché (1847) 16. - Type: Hort. Bot. Berol. (holo B; iso U), origin unknown.

Ficus planicostata Kunth \& C.D. Bouché (1847) 16. - Ficus populnea Willd. forma planicostata (Kunth \& C.D. Bouché) Warb. (1903) 479. - Type: Hort. Bot. Berol. s.n. (holo B; iso U), origin unknown.

Urostigma populneum (Willd.) Miq. forma mexicanum Miq. (1847) 537. - Type: Beechey s.n. (in herb. Hooker) (holo K), Mexico, Acapulco.

Urostigma schiedeanum Miq. (1847) 539. - Type: Schiede \& Deppe 1116 (holo U; iso B, K, LE), Mexico, Veracruz, near Papantla, Hda. La Laguna.

Urostigma erythrostictum Miq. (1847) 540. - Ficus erythrosticta (Miq.) Miq. (1867b) 298. - Type: Parker s.n. (holo K), Guyana, Demerara.

Urostigma cestrifolium (Schott) Miq. var. major Miq. (1847) 541. - Type: Von Martius s.n. (holo U), Brazil, 'In sylvis arboriginalibus Paraensibus'.

Urostigma geminum Miq. (1847) 547. - Ficus gemina (Miq.) Miq. (1867b) 298. - Type: Ruiz s.n. (holo U; iso B, BR, G, P), Peru, without locality (or Pozuzo?).

Pharmacosycea laurifolia Miq. (1848) 71. - Ficus daphniphylla Miq. (1867b) 300. - Type: Von Martius s.n. (lecto M; isolecto B, U), Brazil, 'Prov. Rio Negro', Rio Japurá.

Pharmacosycea peruviana Miq. (1848) 72. - Ficus peruviana (Miq.) Rossberg (1937) 61. - Type: Mathews 2061 (holo K; iso E), Peru, without locality.

Urostigma baccatum Liebm. (1851) 327. - Ficus baccata (Liebm.) Miq. (1867b) 299. - Type: Liebmann 14309 (holo C; iso F, P), Mexico, Oaxaca, near Tehuantepec, Hda. Santa Cruz.

Urostigma sapidum Liebm. (1851) 327. - Ficus sapida (Liebm.) Miq. (1867b) 298. - Type: Oersted 14327 (lecto C), Costa Rica, near Escaru.

Urostigma turbinatum Liebm. (1851) 328. - Ficus turbinata (Liebm.) Miq. (1867b) 298, non Willd. (1806), nec Pittier (1937). - Type: Liebmann 14336 (holo C; iso GH, K, LE, P, U), Mexico, Oaxaca, Guatulco.

Urostigma rolanderi Liebm. (1851) 329. - Ficus rolanderi (Liebm.) Miq. (1867b) 298. - Type: Rolander s.n. (holo C; iso B), Surinam, without locality.

Urostigma subtriplinervium (Mart.) Miq. forma major Miq. (1853) 99. - Type: Gardner 4354 (lecto K), Brazil, Goiás, between São Domingos and 'Katte'.

Ficus suffocans Griseb. (1859) 150. - Type: March 682 (lecto NY; isolecto GH, K), Jamaica, without locality.

Ficus ochroleuca Griseb. (1859) 151. - Type: March 1449 (holo GOET), Jamaica, without locality. Urostigma sulcipes Miq. (1862) 413. - Ficus sulcipes (Miq.) Miq. (1867) 298. - Type: Schiedde \& Deppe 1091 (holo U; iso B), Mexico, near Atlacomulco.

Ficus sonorae S. Watson (1889) 78. - Type: Palmer 92 (holo GH; iso K, NY, US), Mexico, Sonora, Guaymas.

Ficus fasciculata S. Watson (1889) 78, non Benth. (1873), nec King (1888). - Type: Palmer 646 (holo GH; iso GH, NY, US), Mexico, Sonora, Guaymas.

Ficus grabhamii Britton (1914) 51. - Type: Harris \& Britton 10547 (lecto NY; isolecto K, P), Jamaica, Silver Hill to Hardware Gap.

Ficus halliana Britton (1914) 51. - Type: Harris \& Britton 10765 (holo NY; iso B, US), Jamaica, John Crow (Blake) Mountains.

Ficus morantensis Britton (1914) 51. - Type: Britton 4115 (holo NY; iso BM, NY), Jamaica, St. Thomas, Morant Point.

Urostigma subtriplinervium (Mart.) Miq. forma ellipticum Herzog (1915) 75. - Ficus elliptica (Herzog) Herter (1940) 151, non Kunth (1817). - Type: Herzog 1398 (holo L; iso G), Bolivia, Santa Cruz, near Santa Cruz de la Sierra.

Ficus broadwayi Urb. (1917) 110. - Type: Broadway 4382 (holo B; iso E, F, G, GH, K, L, US), Tobago, near Lambeau.

Ficus mendelsonii Britton (1922) 330. - Type: Britton, Hazen \& Mendelson 879 (holo NY; iso US), Trinidad, between North Post and Maqueiripe.

Ficus tapajozensis Standl. (1933) 11. - Type: Capucho 381 (holo F), Brazil, Pará, Tapajós region, Boa Vista. 
Ficus palmicida Pittier (1937) 69. - Type: Pittier 12324 (holo VEN; iso A, M, NY, US), Venezuela, Guárico, La Cruz Rubiera.

Ficus kanukuensis Standl. (1939) 174. - Type: A.C. Smith 3143 (holo F; iso A, B, G, K, LE, MO, NY, P, S, U, US), Guyana, Kanuku Mts.

Ficus garcesii Dugand (1942a) 45. - Type: Garcés O. 4 (holo COL; iso COL, F, US), Colombia, Valle, between Palmira and Cerrito, Hda. El Trejito, $1000 \mathrm{~m}$.

Ficus trachelosyce Dugand (1942a) 69. - Type: Hno. Elias 682 (holo US), Colombia, Atlántico, Piojo.

Ficus savannarum Standl. (1948) 298. - Type: Maguire \& Fanshawe 23292 (holo F; iso A, K, MO, NY, P, US), Guyana, Kaieteur Plateau.

Distribution - From southern Mexico through Central America to Jamaica and in South America to western Ecuador, the Guianas, eastern Brazil, and Paraguay; in wet to dry (evergreen to deciduous) forest; at altitudes up to $2000 \mathrm{~m}$.

Note - The following informal entities can be distinguished:

a. 'pertusa-form' with figs $0.4-1 \mathrm{~cm}$ diam. without protracted apex and laminas mostly up to $10 \mathrm{~cm}$ long, occurring in the greater part of the species range;

b. 'subtriplinervia-form' with figs (mostly) $0.3-0.4 \mathrm{~cm}$ diam. and laminas smaller than on average in the 'pertusa-form' and the figs shortly pedunculate, occurring in Central Brazil;

c. 'padifolia-form' with figs 1-2 cm diam. without protracted apex and the opening to the sunken ostiole narrow, the lamina usually larger than in the 'pertusa-form', occurring in Mexico and Central America and in South America mainly in the western part of the continent, also in Central Brazil;

d. 'arpazuasa-form', largely similar to the 'padifolia-form' but the opening to the ostiole crateriform and with a 'glandular' margin, confined to eastern Brazil (Bahia to Rio Grande do Sul);

e. 'broadwayi-form' distinct from the co-occurring 'pertusa-form' in the larger figs (1-2 cm diam.) on longer peduncles and in larger (10-20 cm long), usually firmly coriaceous laminas, ranging from Trinidad and Tobago through the Guianas to eastern Brazil;

f. 'trachylosyce-form' with small to large figs of which the apex protracted up to $1 \mathrm{~cm}$ long, from Central America to north-western South America.

\section{ACKNOWLEDGEMENTS}

Some of the data in this study have been acquired during a visit to herbarium E(dinburgh), financed by the European Commission's Research Infrastructure Action via the SYNTHESYS Project and a visit to herbarium F (Chicago), financed by a Robert O. Bass scholarship. The author is much indebted to Drs. G. Zijlstra (Utrecht) for critically reading the manuscript and the improvements proposed.

\section{REFERENCES}

Aiton, W. 1789. Hortus Kewensis ed. 1, 3. London.

Aublet, J.B.C.F. 1775. Histoire des plantes de la Guiane française. London, Paris.

Bentham, G. 1873. Flora australiensis 6. London.

Berg, C.C. 1989. Classification and distribution of Ficus. In: Comparative biology of figs. Experientia 45: 605-611.

Berg, C.C. 1992. Ulmaceae, Moraceae, Cecropiaceae, Urticaceae, and Casuarinaceae. In: A.R. A. Görts-van Rijn (ed.), Flora of the Guianas, Ser. A., Fasc. 11. Koenigstein. 
Berg, C.C. 2003. Proposals to conserve the names Ficus citrifolia against F. caribaea, F. maxima with a conserved type, F. aurea against F. ciliolosa, and F. americana against F. perforata (Moraceae). Taxon 52: 368-370.

Berg, C.C. \& E.J.H. Corner. 2005. Moraceae - Ficus. Flora Malesiana, Ser. 1, 17/2. Leiden.

Berg, C.C. \& E. Simonis. 1981. The Ficus flora of Venezuela: Five species complexes discussed and two new species described. Ernstia 6: 1-12.

Berg, C.C. \& J.E. Simonis. 2000. Flora de Venezuela: Moraceae: 5-189 (indices: 250-269). Fundación Instituto Botánico de Venezuela 'Dr. Tobias Lasser', Caracas.

Berg, C.C., M. Vázquez Avila \& F. Kooy. 1986. Ficus species of Brazilian Amazonia and the Guianas. (Studies on the Flora of the Guianas 18). Acta Amazonica 14, 1/2, Suppl. (Contribuições do Projecto Flora Amazônica 1): 159-194.

Berg, C.C. \& X. Villavicencio. 2004. Taxonomic studies on Ficus (Moraceae) in the West Indies, extra-Amazonian Brazil, and Bolivia. Ilicifolia 5: 1-132, t. 1-45.

Boldingh, I. 1914. Flora of the Dutch West Indian Islands 2. Leiden.

Britton, N.L. 1914. In: W. Fawcett \& A.B. Rendle, Flora of Jamaica 3. London.

Britton, N.L. 1922. Studies of West Indian plants - X. Bull. Torrey Bot. Club 48: 327-343.

Brummitt, R.K. 2005. Report of the Committee for Spermatophyta: 56. Taxon 54: 527-536.

Burger, W.C. 1973. Notes on the flora of Costa Rica, 3: New species in the Moraceae. Phytologia 26: $421-434$.

Carvajal, S. \& X.M. Cuevas-Figueroa. 2003. Ficus rzedowskiana (Moraceae, subg. Urostigma) una especie nueva de México. Bol. Inst. Bot. Univ. Guadalajara 11, 2: 37-40.

Casaretto, G. 1842. Novarum stirpium brasiliensium decades 1: 1-16. Genova.

Chodat, R. 1920. Urticiflores. In: R. Chodat \& W. Vischer, La végétation du Paraguay. Bull. Soc. Bot. Genève, sér. 2, 11: 226-258.

D'Arcy, W.G. 1973. New names for Neotropical plants. Phytologia 25: 116.

Desvaux, N.A. 1825. Ficus guianensis. In: W. Hamilton, Prodromus plantarum Indiae occidentalis: 62. London.

DeWolf, G.P. 1975. Ficus. In: C.C. Berg \& G.P. DeWolf, Moraceae. In: J. Lanjouw \& A.L. Stoffers (eds.), Flora of Suriname 5, 1: 228-265. Leiden.

Domin, K. 1930. Ficus lentiginosa Vahl in Dominica. Acta Bot. Bohem. 9: 46-48.

Dugand, A. 1942a. Nuevas especies colombianas de género Ficus. Caldasia 1, 4: 25-74.

Dugand, A. 1942b. Dos aduciones a las especies nuevas colombianas del género Ficus. Caldasia 1, 5: $37-39$.

Dugand, A. 1943a. Nuevas especies de Ficus de Colombia y del Ecuador. Caldasia 2: 77-80.

Dugand, A. 1943b. Nuevas nociones sobre el género Ficus en Colombia. Caldasia 2: 265-283.

Dugand, A. 1944. Nuevas nociones sobre el género Ficus en Colombia II. Caldasia 2: 375-386.

Dugand, A. 1955. Nuevas nociones sobre el género Ficus en Colombia VII. Caldasia 7: 213-245.

Fawcett, W. \& A.B. Rendle. 1914. Flora of Jamaica 3. London.

Grisebach, A.H.R. 1859. Flora of the British West Indian Islands (part 2). London.

Hassler, E. 1919. Moracearum paraguariensium conspectus. Annuaire Conserv. Jard. Bot. Geneve 21: $109-131$.

Hemsley, W.B. 1883. Biologia Centrali-Americana, Botany. 3. London.

Herter, W.G. 1940. Plantae uruguayenses novae vel criticae. Revista Sudamer. Bot. 6: 129-155.

Herzog, Th. 1915. Die von Dr. Th. Herzog auf seiner zweiten Reise durch Bolivien in den Jahren 1910 und 1911 gesammelten Pflanzen. II. Teil. Meded. Rijks-Herb. 27: 1-90.

Hooker, W. J. \& G. A.W. Arnott. 1838. The botany of Captain Beechey's voyage (part 7). London.

Jacq. see Von Jacquin.

King, G. 1888. Ficus. In: J.D. Hooker, The Flora of British India 5: 494-537. London.

Kunth, C.S. 1817. Urticeae. In: F.W.H.A. von Humboldt, A.J.A. Bonpland \& C.S. Kunth, Nova genera et species plantarum 2: 28-50. Paris.

Kunth, C.S. \& C.D. Bouché. 1847. Ficus. In: C.S. Kunth, Enumeratio synoptica Ficus specierum cum novarum tum cognitarum hortii regii botanici berolinensis. In: H.F. Link, C.S. Kunth \& C.D. Bouché, Index seminum horto botanico Berolinensi 1846: 14-22. Berlin.

Kuntze, C.E.O. 1898. Revisio generum plantarum 3, 2. Leipzig. 
Liebmann, F.M. 1851. Mexicos og Central-Americas neldeagtige planter (Ordo: Urticaceae) indbefattende familierne: Urticeae, Moreae, Artocarpeae og Ulmaceae. - Kongel. Danske Vidensk. Selsk. Skr., Naturvidensk. Math. Afd., ser. 5, 2: 285-343.

Link, H.F. 1822. Enumeratio plantarum hort regii botanici berolinensis altera 2. Berlin.

Linnaeus, C. 1775. Plantae surinamensis. Uppsala.

Linnaeus Jr., C. 1782. Supplementum plantarum. Braunschweig.

Lundell, C.L. 1961. Plantae Mayanae - II. Collections from Peten and Belice. Wrightia 2: 111126.

Lundell, C.L. 1975. Studies of American plants - X. Wrightia 5: 151-185.

Mart. see Von Martius.

Miller, P. 1768. The gardeners dictionary, ed. 8. London.

Miquel, F.A.W. 1847. Prodromus monographiae Ficuum. London J. Bot. 6: 514-588, t. 21-22.

Miquel, F.A.W. 1848. Prodromus monographiae Ficuum. London J. Bot. 7: 64-78, t. 2; 109-116, t. $3 ; 221-236$, t. $5 ; 425-442$, t. $6-7$ A; $451-471$, t. $7 \mathrm{~B}-11$.

Miquel, F.A.W. 1853. Urticinae. In: C.F.P. von Martius, Flora Brasiliensis 4, 1: 77-218, t. 25-70. Leipzig.

Miquel, F.A.W. 1854. Artocarpeae. Tribus I. Ficeae. In: B. Seemann, The botany of the voyage of H.M.S. Herald: 195-196. London.

Miquel, F.A.W. 1862. Over de geographische verspreiding der Ficeae, met een nader onderzoek omtrent de soorten, welke in Amerika, noordelijk van de landengte van Panama voorkomen. Verslagen Meded. Afd. Natuurk. Kon. Akad. Wetensch. 13: 382-415.

Miquel, F.A.W. 1867a. Artocarpeae. Ann. Mus. Bot. Lugduno-Batavi 3: 210-235.

Miquel, F.A.W. 1867b. Annotationes de Ficus speciebus. Ann. Mus. Bot. Lugduno-Batavi 3: 260-300.

Murray, E. 1983. Notae Spermatophytae No. 2. Kalmia 13: 3-32.

Nuttall, T. 1846. The North American sylva 2. Philadelphia.

Pittier, H. 1937. Ensayo sobre la clasificación de las especies Venezolanas del género Ficus. Bol. Soc. Venez. Ci. Nat. 4, 30: 44-80.

Pittier, H. 1941. Notas dendrologicas de Venezuela. VI. Moraceae. Bol. Soc. Venez. Ci. Nat 7: $133-135$.

Pittier, H. 1943. Notas dendrologicas de Venezuela. VIII. Moraceae. Bol. Soc. Venez. Ci. Nat. 8: 257-260.

Pittier, H. 1944. Notas dendrologicas de Venezuela. IX. Moraceae. Bol. Soc. Venez. Ci. Nat. 9: 119-120.

Richard, A. 1841-1851. Plantes vasculaires. In: R. de la Sagra, Historia física, política y natural de la isla de Cuba. Paris.

Ridley, H.N. 1916. Report on the botany of the Wollaston expedition to Dutch New Guinea 1912-13. Trans. Linn. Soc. London, Bot., 9: 1-269.

Rossberg, G. 1935. Zur Kenntnis der westindischen Moraceen II. Notizbl. Bot. Gart. Berlin-Dahlem 12: $565-587$.

Rossberg, G. 1937. Beitrag zur Kenntnis der amerikanischen Moraceen. Repert. Spec. Nov. Regni Veg. 42: 59-61.

Rusby, H.H. 1907. An enumeration of the plants collected in Bolivia by Miguel Bang, with descriptions of new genera and species. Bull. New York Bot. Gard. 4: 309-470.

Sandwith, N. Y. 1932. Contributions to the flora of Tropical America. Bull. Misc. Inform. Kew 1932: 209-229.

Schott, H.W. 1827. Fasciculus plantarum brasiliensium. In: K.P.J. Sprengel, Systema Vegetabilium 4, 2: 403-410. Göttingen.

Sprengel, K.P.J. 1826. Systema Vegetabilium 3. Göttingen.

Standley, P.C. 1917. The Mexican and Central American species of Ficus. Contr. U.S. Natl. Herb. 20: $1-35$, index vii-viii.

Standley, P.C. 1929. Studies of American plants I. Publ. Field Mus. Nat. Hist., Bot. Ser. 4: 197299.

Standley, P.C. 1932. Three new trees from Colombia. Trop. Woods 32: 20-21. 
Standley, P.C. 1933. New trees from the Tapajoz River, Brazil, with a list of vernacular names. Trop. Woods 33: 11-24.

Standley, P.C. 1935. New plants from the Yucatan Peninsula. Publ. Carnegie Inst. Wash. 461: 51-91.

Standley, P.C. 1937a. Ficus. In: J.F. Macbride, Flora of Peru, part II. Publ. Field Mus. Nat. Hist., Bot. Ser. 13, 2: 299-308.

Standley, P.C. 1937b. Studies of American plants VII. Publ. Field Mus. Nat. Hist., Bot. Ser. 17: $155-224$.

Standley, P.C. 1939. Moraceae. In: A.C. Smith, Notes on a collection of plants from British Guiana. Lloydia 2: $174-175$.

Standley, P.C. 1948. Moraceae. In: B. Maguire et al., Plant explorations in Guiana in 1944, chiefly to the Tafelberg and the Kaieteur plateau - III. Bull. Torrey Bot. Club 75: 293-299.

Standley, P.C. \& J.A. Steyermark. 1940. Studies on Central American plants - I. Publ. Field Mus. Nat. Hist., Bot. Ser. 22: 221-321.

Standley, P.C. \& L.O. Williams. 1951. Plantae Centrali-Americanae, II. Ceiba 1: 231-255.

Stehlé, H., M. Stehlé \& L. Quentin. 1938. Catalogue des Phanérogames et fougères. In: H. Stehlé, Flore de la Guadeloupe et dépendances 2, 1. Basse-Terre.

Steudel, E.G. 1840. Nomenclator botanicus ed. 2. Stuttgart.

Torres-Romero, J.H. 1985. Una nueva especie de Ficus (Moraceae) de Colombia. Caldasia 14, 67: 207-210.

Urban, I. 1900. Species novae, praesertim portoricences. Supplementum. Symbolae Antillanae 1, 3: 472-481. Berlin, Paris, London.

Urban, I. 1905. Flora Portoricensis. Moraceae. In: I. Urban, Symbolae Antillanae 3: 195-199. Leipzig, Paris, London.

Urban, I. 1917. Sertum antillanum. IV. Repert. Spec. Nov. Regni Veg. 15: 98-112.

Urban, I. 1920-1921. Flora Domingensis. In: I. Urban, Symbolae Antillanae 8: 1-855. Leipzig, Paris, London.

Vahl, M. 1805. Enumeratio plantarum 2. Copenhagen.

Vellozo, J.M. da C. 1831. Flora Fluminensis, Icones. Paris.

Von Jacquin, N.J. 1767. Observationum Botanicarum 2. Wien.

Von Martius, C.F.P. 1841. Herbarium florae brasiliensis. Flora 24 (2. Beibl.): 1-112.

Warburg, O. 1903. Ficus Linn. In: I. Urban, Symbolae Antillanae 3: 453-491. Leipzig, Paris, London.

Watson, S. 1889. Contributions to American botany. Proc. Amer. Acad. Arts 24: 36-86.

Willdenow, C.L. 1806. Species plantarum 2. Berlin. 